UDC 636.2.082.22; 636.2.064

COBISS.SR-ID: 220288268

Original research paper

Acta Agriculturae Serbica, Vol. XX, 40 (2015); 99-106

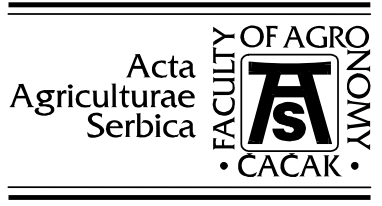

\title{
Comparison of linear type traits of daughters of Simmental bulls
}

\author{
M. Lazić ${ }^{1}$, Z. Spasić, Dragana Grčak ${ }^{2}$, Z.Z. Ilić ${ }^{2}$, B. Milošević ${ }^{2}$ and \\ S. Rakonjac ${ }^{3}$ \\ 1 Agriculture Cooperative "Eko Zupa", Aleksandrovac, Serbia \\ 2 University of Priština, Faculty of Agriculture, Lešak, Serbia \\ 3 University of Kragujevac, Faculty of Agronomy, Čačak, Serbia
}

\begin{abstract}
Linear assessment of the type and body development provides very important information on the total value of animals for the purpose of breeding animals selected and classified into classes. Determination of the average values of exterior parameters, especially non-measurable traits, is useful in defining breeding objectives and formulating effective plans and programs. Given that previous studies found statistically significant differences among daughters of Simmental bulls for some properties of the exterior, the objective of this paper was to compare linear type traits and body development of daughters of Simmental bulls in the Rasina region. Based on linear type traits and body development, the most significant results were achieved by daughters of bull No. 1464 (Ralfus) for the frame, muscularity and form, and by daughters of bull No. 1488 (Hormaz) for udder appearance. If each attribute is analyzed separately, bull No. 1411 (Horau) is equally significant for the traits for which its daughters showed the best performance.
\end{abstract}

Key words: body development, exterior, linear scoring, cattle, type traits.

Received: 5 September 2015 / Accepted: 18 November 2015 


\section{Introduction}

The basis for selection work is knowledge of the quality of bull sires used for conception, as well as how major traits are passed on to their progeny (Pantelic et al. 2011a). In Serbia, annually, only very few bulls are tested, which is insufficient to ensure greater and faster genetic improvement in production and reproduction traits of the Simmental population of cattle (Pantelic el al. 2009). Many Serbian authors have studied Simmental cattle (Petrovic et al., 2003; Petrovic et al., 2010; Niksic et al. 2012; Spasic et al. 2015), which is the most numerous breed cattle with great potential.

Type and body development scores are very important indicators of the production ability of cows, their potential to consume sufficient quantities of food, produce technologically high quality milk, reduce the use of energy in production and remain as long as possible in exploitation (Pantelic et al. 2011b). According to many authors, proper body development of productive cows is the basis for normal morpho-physiological functions. Deficiencies in type traits give rise to lower production, poor health and premature exclusion from the cow herd (Pantelic et al. 2007b). To improve the body development of the domestic Simmental breed population and use it as the basis for improved functional milk production, in addition to using the existing results, it is essential to pay attention to additional parameters primarily related to the knowledge of the phenotypic and genotypic correlation traits of body development, fertility and productivity within one sex and between the sexes (Bogdanovic et al. 2006). Taking into account the appearance of descendants and their proper selection, greatly reducing the possibility of transferring negative characteristics of parental couples can wear it as a recessive, which is due to the massive use of artificial insemination can quickly spread in the population (Posavi et al. 1999; Pantelic et al. 2007a).

An exceptionally important aspect in cattle production, in terms of production and economy, is the provision of normal and regular fertility (Niksic et al. 2012). Based on the analysis of reproductive traits, Lazic and Spasic (2015) pointed out that special attention should be given to raising breeding heifers, especially in their first conception, in order that their reproductive potential is fully exploited. However, in accordance with the breeding program on quality breeding animals involving several stages of selection and assessment, the exclusion from reproduction due to small errors in the exterior is the consequence of assessors' skill, quality and objectivity (Sakic et al. 2004). Pantelic et al. (2007a) suggest that the inclusion of linear type in the assessment of the breeding value of cows contributes to the reliability of estimates, thus positively affecting overall selection and performance production. 


\section{Materials and methods}

To determine the average values of linear type traits and body development in daughters of Simmental bulls, documented data were obtained from the main breeding organization developing and conducting breeding programs in the Rasina region which belongs to the statistical region of Šmadija and Western Serbia. The Kruševac Agricultural Extension Service based in Kruševac is the regional breeding organization which conducts activities in the administrative Rasina District.

Research covered a total of 180 randomly selected daughters of Simmental bulls $(1411,1464,1488)$ with the same number of offspring. The samples analyzed included quality breeding animals that were subjected to several stages of selection and assessment, in accordance with the breeding program. The first step in the selection process was based on the breeding values of parents and offspring body development. Then, the animals were tested after pregnancy and after the first, second and third parturition. Testing, selection and assessment of cattle were performed after parturition. The Simmental cattle used in this study were preventively treated and had no health problems, according to the official note.

Linear assessment of the type traits of Simmental cattle was performed in accordance with the "System '97" linear scoring method, used in the main breeding program in the Republic of Serbia. For type evaluation and assessment between two possible biological extremes, criteria set by the main breeding organizations were used, depending on the breeding goal. Body development was assessed using the following measuring equipment: a Lydtin stick, a divider, a protractor and a measuring tape.

\section{Results and Discussion}

Muscle development of cattle was evaluated based on the occupancy of the aft fuselage muscle tissue, with length of the leg and muscles of the pelvis and lumbar back considered (Pantelic et al. 2005, Pantelic et al. 2007a). The results (see Table 1) indicate that muscle development ranged from average to full among the daughters of Simmental bulls in the Rasina region. Identical results were reported by Posavi et al. (1999), Pantelic et al. (2007a), Pantelic et al. (2007b) and Spasic et al. (2015). 
Table 1. Mean \pm standard error of linear type traits of daughters of Simmental bulls

\begin{tabular}{llll}
\hline \hline \multicolumn{1}{c}{ Trait $(S c a l e ~ 1-9)$} & $\begin{array}{l}\text { Horau } \\
(H B 1411)\end{array}$ & $\begin{array}{l}\text { Ralfus } \\
(H B 1464)\end{array}$ & $\begin{array}{l}\text { Hormaz } \\
(H B 1488)\end{array}$ \\
\hline $\begin{array}{l}\text { TYPE OR FRAME } \\
\text { Height of the cross }\end{array}$ & $5.78 \pm 0.09$ & $5.88 \pm 0.08$ & $6.12 \pm 0.07$ \\
Length of the pelvis & $6.03 \pm 0.09$ & $5.90 \pm 0.09$ & $5.62 \pm 0.06$ \\
Width of the pelvis & $6.33 \pm 0.11$ & $5.93 \pm 0.09$ & $6.03 \pm 0.05$ \\
Angle of the pelvis & $4.18 \pm 0.08$ & $4.40 \pm 0.07$ & $4.08 \pm 0.11$ \\
Depth of the hull & $6.50 \pm 0.08$ & $6.68 \pm 0.07$ & $6.38 \pm 0.08$ \\
$\quad$ MUSCULARITY & & & \\
Muscularity & $6.67 \pm 0.07$ & $6.80 \pm 0.05$ & $6.78 \pm 0.07$ \\
$\quad$ FEET AND LEGS & & & \\
Angle of the hock & $4.52 \pm 0.11$ & $4.65 \pm 0.08$ & $4.33 \pm 0.09$ \\
Development of hock joint & $4.93 \pm 0.06$ & $4.82 \pm 0.06$ & $4.77 \pm 0.06$ \\
Pasterns & $5.47 \pm 0.06$ & $5.67 \pm 0.06$ & $5.53 \pm 0.06$ \\
Height- appearance hoof & $5.73 \pm 0.09$ & $5.77 \pm 0.08$ & $6.05 \pm 0.12$ \\
$\quad$ UDDER & & & \\
Fore udder length & $5.97 \pm 0.05$ & $6.27 \pm 0.09$ & $6.03 \pm 0.07$ \\
Rear udder length & $5.93 \pm 0.06$ & $6.30 \pm 0.08$ & $6.10 \pm 0.08$ \\
Rear udder height & $5.20 \pm 0.09$ & $5.35 \pm 0.09$ & $4.97 \pm 0.07$ \\
Central ligament & $4.43 \pm 0.10$ & $4.27 \pm 0.07$ & $4.73 \pm 0.07$ \\
Udder depth & $5.73 \pm 0.09$ & $6.10 \pm 0.09$ & $5.97 \pm 0.08$ \\
Position of front teats & $6.02 \pm 0.06$ & $5.80 \pm 0.07$ & $6.03 \pm 0.05$ \\
Position of teats & $5.27 \pm 0.11$ & $4.87 \pm 0.06$ & $5.08 \pm 0.07$ \\
Length of teats & $5.03 \pm 0.07$ & $4.80 \pm 0.05$ & $5.12 \pm 0.06$ \\
Teat thickness & $4.67 \pm 0.06$ & $4.90 \pm 0.06$ & $4.83 \pm 0.05$ \\
Udder cleanness & $8.70 \pm 0.12$ & $8.78 \pm 0.07$ & $8.92 \pm 0.04$ \\
\hline \hline
\end{tabular}

Height of the cross is measured with a stick vertically from the ground to the highest point of the cross, or the point where the line connecting the hips cuts the spine. Table 1. presents the average heights of the cross of daughters of Simmental bulls, which are identical to the results of other authors (Posavi et al., 1999; Spasic et al. 2015). Spasic et al. (2015) observed a statistically significant difference $\left(t_{\exp }, \mathrm{P} \leq 0.01\right)$ between daughters of bull Horau (HB 1411) and daughters of bull Hormaz (HB 1488) for height of the cross, while the result for daughters of bull Ralfus (HB 1464) and daughters of bull Hormaz (HB 1488) was also statistically significant $\left(t_{\exp }, \mathrm{P} \leq 0.05\right)$. Length of the pelvis is strongly correlated with the length of the body, and was measured with a tape or a stick from the front edge side of the tubercle (tuber coxae) to the back edge of 
buttocks (Sakic et al. 2004), while the width of the pelvis at hips was measured with a stick, from the external point of one tubercle to the outer point of the other tubercle (Pantelic et al. 2005). Table 1 presents the average length of the pelvis and width of the pelvis at the hips. Similar results were reported by other authors (Posavi et al. 1999; Spasic et al. 2015). Spasic et al. (2015) found statistically significant difference $\left(F_{\text {exp }}, \mathrm{P} \leq 0.01\right)$ between bulls - fathers for the values of the length of the pelvis and width of the pelvis at the hips.

The position of the pelvis was assessed as extremely concave (score 1) to extremely deburred (score 9), the ideal position of the pelvis being when the buttock bone is $4-5 \mathrm{~cm}$ below the underlined horizontal line from the upper edge of the side crest (Sakic et al. 2004). The average angle of the pelvis (Table 1) is identical to the results of other authors (Posavi et al. 1999; Spasic et al. 2015). Depth of the hull was measured with a stick vertically from the back edge of the breastbone to the top of the ridge, with the mean depth (Table 1) identical to the results of Posavi et al. (1999) and Spasic et al. (2015). Spasic et al. (2015) observed a statistically significant difference $\left(F_{\exp }, \mathrm{P} \leq 0.05\right)$ between bulls fathers for depth of the hull and angle of the pelvis.

Height (appearance) of the hooves was measured vertically from the substrate. Table 1 presents mean height, which is identical to the results of other authors (Posavi et al., 1999; Spasic et al. 2015). The average value of the ankle joint suggests that the ankle is relaxed and properly developed. For feet and leg properties, Spasic et al. (2015) recorded statistically significant differences $\left(F_{\text {exp }}\right.$, $\mathrm{P} \leq 0.05$ ) for hoof height (appearance), and statistically non-significant differences for other traits between daughters of Simmental bulls. Table 1 presents the average value of the linear score for the position of hind legs (angled hock) and development (expression) of the ankle joint, as seen from the side and from behind, and unclear development of the ankle joint and the normal position of the hindquarters (i.e. correct) were found. Identical results were reported by Posavi et al. (1999) and Spasic et al. (2015), while Pantelic et al. (2007a) and Pantelic et al. (2007b) found somewhat higher average values.

As for udder traits in daughters of Simmental bulls, Spasic et al. (2015) observed statistically significant differences $\left(F_{\text {exp }}, \mathrm{P} \leq 0.001\right)$ in the central ligament and udder depth, and statistically significant differences $\left(F_{\exp }, \mathrm{P} \leq 0.01\right)$ for many traits, except for teat thickness and udder cleanness. In recent decades, selection in dairy cattle has been mainly focused on the genetic improvement of productive traits, which has negatively affected many functional properties (Raguz et al. 2009). The results on linear type traits and body development for udder traits are as follows: length of front and rear udders: medium to long spacious, height of rear udders: medium, the central ligament: weak to medium developed, udder depth: medium, the position of front udders: outward, vertical position, teat length: normal and medium, udder: mostly clear. Identical results were determined by Posavi et al. (1999) and Spasic et al. (2015), while Pantelic 
et al. (2007a) and Pantelic et al. (2007b) reported somewhat higher average values in their studies.

\section{Conclusion}

Based on linear type traits and body development, the most significant results for the frame, muscularity and form were achieved by daughters of bull No. 1464 (Ralfus), and those for udder appearance by daughters of bull No. 1488 (Hormaz). If each attribute is analyzed separately, bull No. 1411 (Horau) is equally significant for the traits for which its daughters showed the best performance. Despite the fact that Simmental cattle are well adapted in Europe, the estimated value based on their external appearance in Serbia is not satisfactory. Taking into account the research of other authors, future analysis should be directed towards potential correlations between type traits, with the information obtained having multiple significance in the selection of cows.

\section{References}

Bogdanovic V., Djedovic R., Perisic P., Petrovic M.M. (2006): Application of the tehnology of improvement of body development traits as a basis for milk production in Simmental cattle population in Serbia. Biotechnology in Animal Husbandry, 22: 33-44.

Lazic M., Spasic Z. (2015): Linear regression and correlation of reproductive traits in population of Holstein-Friesian cattle. In: Proceedings "IX Conference of Agronomy Students with international participation" Faculty of Agronomy, Cacak, Serbia. 56-64

Niksic D., Pantelic V., Ostojic-Andric D., Perisic P., Petricevic M., Djedovic R., Lazarevic M. (2012): Results of the biological test of Simmental buls in central Serbia. Biotechnology in Animal Husbandry, 28: 497-507.

Pantelic V., Petrovic M., Stojic P., (2005): Uputstvo za linearno ocenjivanje tipa i kondicije goveda. Institut za stočarstvo, Beograd

Pantelic V., Skalicki Z., Petrovic M.M., Latinovic D., Aleksic S., Miscevic B., Ostojic D. (2007a): Linearno ocenjivanje bikovskih majki simentalske rase. Savremena poljoprivreda, 56: 49-53.

Pantelic V., Skalicki Z., Petrović M.M., Aleksić S., Miscevic B., Ostojic-Andric D. (2007b): Variability of linearly evaluated traits of type of Simmental bull dams. Biotechnology in Animal Husbandry. 23: 201-208.

Pantelic V., Novakovic Z., Ostojic-Andric D. (2009): Selection of bull dams in population of Simmental cattle. Biotechnology in Animal Husbandry. 25: 301-313

Pantelic V., Plavsic M., Trivunovic S., Aleksic S., Sretenovic Lj., Ostojic-Andric D., Niksic D. (2011a): The evaluation of breeding 
value of Simmental bulls for milk performance in Serbia. Biotechnology in Animal Husbandry. 27: 127-135.

Pantelic V., Niksic D., Trivunovic S. (2011b): Variability and heritability of type traits of Holstein-Friesian bull dams. Biotechnology in Animal Husbandry. 27: $305-313$.

Posavi M., Kap M., Ėurik I., Kljujev A. (1999): Procjena heritabiliteta za svojstva vanjstine linerano ocijenjenih metodom "System '97". Poljoprivredna znanstvena smotra (ACS), 64: 59-65.

Petrovic D.M., Gutic M., Skalicki Z., Bogdanovic V. (2003): The Effect of Age at First Insemination on Longevity and Lifetime Production Traits in Simmental Cows. Acta Agriculturae Serbica. 8: 57-61.

Petrovic D.M., Bogdanovic V., Bogosavljevic-Boskovic Snezana, Djokovic R. (2010): Effect of Systematic Factors on Gestation Length in Simmental Cows. Acta Agriculturae Serbica. 15: 31-37.

Raguz N., Ganter V., Jovanovic S. (2009): Dugovjecnost mlijecnih pasmina goveda. Stocarstvo. 63: 187-202.

Spasic Z., Milosevic B., Lazic M., Ciric S., Stolic N., Ilic Z., Pesic B. (2015): Linear evaluation of primiparous Simmental cows. In: $5^{\text {th }}$ International Conference "Research People and Actual Tasks on Multidisciplinary Sciences" (ISSN 1313-7735), 24-28 June 2015, Lozenec, Bulgaria. v.1, pp. 9-13.

Sakic V., Posavi M., Katica V., Softic A. (2004): Linearna procjena vanjštine simentalskog $i$ holštaj-frizijskog goveda. Veterinarski fakultet Univerziteta u Sarajevu, Tempus Project/Sarajevo. 


\title{
KOMPARACIJA LINEARNE OCENE TIPA IZMEĐU KĆERI BIKOVA SIMENTALSKE RASE
}

\author{
M. Lazić ${ }^{1}$ Z. Spasić ${ }^{2}$, Dragana Grěak ${ }^{2}$, Z.Ž. Ilić $^{2}$, B. Milošević ${ }^{2}$ i \\ S. Rakonjac ${ }^{3}$ \\ 1 Zemljoradnička zadruga "Eko Župa", Aleksandrovac, Srbija \\ 2 Univerzitet u Prištini, Poljoprivredni fakultet, Lešak, Srbija \\ 3 Univerzitet u Kragujecu, Agronomski fakultet, Čačak, Srbija
}

\begin{abstract}
Rezime
Linearna ocena tipa $\mathrm{i}$ telesne razvijenosti je veoma važna informacija o ukupnoj vrednosti životinje na osnovu koje se priplodna grla odabiraju i razvrstavaju u klase. Određivanje prosečne vrednosti eksterijernih parametara, naročito nemerivih osobina, predstavlja korisnu informaciju prilikom definisanja odgajivačkog cilja i formulisanja efikasnog plana i programa. S obzirom na to da su u prethodnim saopštenjima dobijene statistički značajne razlike između kćeri bikova simentalske rase za određena svojstva eksterijera, cilj ovog rada predstavlja komparaciju linearne ocene tipa i telesne razvijenosti između kćeri bikova simentalske rase na područiju Rasinskog okruga. Na osnovu linearne ocene tipa i telesne razvijenosti, najznačajnije rezultate ostvarile su kćeri bika broj 1464 (Ralfus) za okvir, muskuloznost i formu, dok su za izgled vimena najznačajnije rezultate ostvarile kćeri bika broj 1488 (Hormaz). Naravno, ukoliko svako svojstvo posmatramo zasebno, bik broj 1411 (Horau) podjednako je značajan za one osobine gde su njegove kćeri imale najbolje retultate.

Ključne reči: telesna razvijenost, eksterijer, linearna ocena, goveda, osobine tipa
\end{abstract}

